\title{
Sensitive Determination of Metal Ions in Drinking Water by Capillary Electrophoresis Coupled with Contactless Conductivity Detection Using 18-Crown-6 Ether and Hexadecyltrimethylammonium Bromide as Complexing Reagents
}

\author{
Wujuan Chen, Fan Gao, Yi Zhang, Yan Zhang, Yi Li, Yating Zhang, Qingjiang Wang*, Pingang He \\ School of Chemistry and Molecular Engineering, East China Normal University, Shanghai, China \\ Email: *qjwang@chem.ecnu.edu.cn
}

How to cite this paper: Chen, W.J., Gao, F., Zhang, Y., Zhang, Y., Li, Y., Zhang, Y.T., Wang, Q.J. and He, P.G. (2016) Sensitive Determination of Metal Ions in Drinking Water by Capillary Electrophoresis Coupled with Contactless Conductivity Detection Using 18-Crown-6 Ether and Hexadecyltrimethylammonium Bromide as Complexing Reagents. American Journal of Analytical Chemistry, 7, 737-747. http://dx.doi.org/10.4236/ajac.2016.711066

Received: July 7, 2016

Accepted: October 22, 2016

Published: October 25, 2016

Copyright $\odot 2016$ by authors and Scientific Research Publishing Inc. This work is licensed under the Creative Commons Attribution International License (CC BY 4.0).

http://creativecommons.org/licenses/by/4.0/

\begin{abstract}
A simple, economical, and sensitive capillary electrophoresis (CE) method integrated with capacitively coupled contactless conductivity detection was developed for the determination of metal ions such as $\mathrm{K}^{+}, \mathrm{Na}^{+}, \mathrm{Mg}^{2+}, \mathrm{Sr}^{2+}, \mathrm{Ca}^{2+}$ in drinking water. 18-Crown-6 ether and Hexadecyltrimethylammonium Bromide (CTAB) were employed as complexing reagents. The effects of electrolyte additives, citric acid buffer solution, and other separation conditions of CE were comprehensively investigated and carefully optimized. The best results were obtained in a running buffer solution composed of citric acid (12 mM), 18-crown-6 ether $(0.2 \mathrm{mM})$, and CTAB (0.015 $\mathrm{mM})$ at $\mathrm{pH}$ 3.5. Under these conditions, a complete separation of five metal ions was successfully achieved in less than $12 \mathrm{~min}$. The limits of detection for the optimal procedure were determined to be in the range of $0.02-0.2 \mathrm{mg} \cdot \mathrm{L}^{-1}$. The repeatability with respect to migration times and peak areas, expressed as relative standard deviations, was better than $2.3 \%$ and $5.1 \%$, respectively. Evaluation of the efficiency of the methodology indicated that it was reliable for the determination of metal ions in six different brands of drinking water samples.
\end{abstract}

\section{Keywords}

Capillary Electrophoresis, Contactless Conductivity Detection, Metal Ions, Food, Drinking Water 


\section{Introduction}

Most of the alkali and alkaline earth metal ions play an important role in numerous processes in the human body, such as volume and osmotic regulation, myocardial rhythm, blood coagulation, and neuromuscular excitability. The detection of any deviation from the normal concentration ranges of these species is very useful in the diagnosis of metabolic disorders and abnormalities [1] [2]. Common metal ions including potassium $\left(\mathrm{K}^{+}\right)$, sodium $\left(\mathrm{Na}^{+}\right)$, magnesium $\left(\mathrm{Mg}^{2+}\right)$, strontium $\left(\mathrm{Sr}^{2+}\right)$, and calcium $\left(\mathrm{Ca}^{2+}\right)$ are monitored routinely in a wide variety of drinking water samples. Access to safe drinking water with appropriate limits of metal ions as nutrients has always been a great challenge. Therefore, nowadays, many drinking water industries are constantly emerging. Diverse factors such as the belief that mineral waters are of medicinal value, fueled by the impression that mineral waters are always associated with metal ions as portrayed in the advertisements, have contributed to this popularity [3]. Determination of metal ions in drinking water is an active topic in analytical science. Therefore, a simple, rapid, and reliable method for the simultaneous determination of these metal ions in real samples is highly desirable.

The traditional methods for the analysis of metal ions in environmental samples include spectrophotometry and atomic absorption spectroscopy, capable of detecting only a single element at a time. Therefore, these methods are time-consuming and laborious [4]. Inductively coupled plasma-mass spectrometry is a powerful tool for elemental analyses except for its high operating costs. Capillary electrophoresis (CE) has emerged as a valuable alternative that offers considerable advantages including rapid analysis, cost-effectiveness, high separation efficiency, and reagent consumption [5]. CE has benefit of simultaneous multielement determination. The traditional detection method used in CE system is optical detection; however, most metal ions lack enough absorbance in the ultraviolet (UV) region, which significantly limits its practical application range [5]. In order to overcome the abovementioned issue, a method involving indirect UV detection was developed [6] [7]. In this method some reagents such as imidazole, possessing an intense chromophore group in the UV region, were added to the running buffer. However, UV-absorbing buffer additives and more complex buffer systems were needed to facilitate indirect absorbance detection [8], which led to weaker quantitative performance [9] [10]. Unlike optical detection techniques, electrochemical detection can be easily miniaturized with no diminution in analytical performance. It includes three detection techniques: amperometric, potentiometric, and conductivity detection. Among these three methods, potentiometric detection is much less widely used than the other two detections and amperometric detection is affected by the $\mathrm{CE}$ voltage. Capacitively coupled contactless conductivity detection $\left(C^{4} D\right)$ is considered as a universal detection technique for $\mathrm{CE}$ and it exhibits a good sensitivity for all the ionic species. The basic principle of conductivity detection involves the measurement of a difference in conductivity between migration analyte zones and the background electrolyte (BGE), which favors the application of $C^{4} D$ for the determination of non-absorbing species [11]. 
Till date, there are few studies describing the CE determination of inorganic ions in formulations of drinking water. Some of these studies have described the determination of $\mathrm{K}^{+}, \mathrm{Na}^{+}, \mathrm{Mg}^{2+}$, and $\mathrm{Ca}^{2+}$ ions in real samples [12] [13] [14] [15]. However, the analysis of elements that have similar electrophoretic mobilities, such as $\mathrm{Mg}^{2+}$ and $\mathrm{Sr}^{2+}$, by $\mathrm{CE}-\mathrm{C}^{4} \mathrm{D}$ has not been frequently described in literature. Nonetheless, the occurrence of $\mathrm{Sr}^{2+}$ in drinking water is very likely. Considering the need to determine different metal ions in drinking water, as well as the analytical difficulties related to the simultaneous separation of some cations, this study aims to describe the separation of five metal ions, which are common and important as nutrients in drinking water. Introduction of a supplementary separation mechanism, based upon the selective complexation of the cation was highly desirable to improve the analyses of ionic samples. Typical protocols for $\mathrm{CE}-\mathrm{C}^{4} \mathrm{D}$ separation of metal ions, in general, involve the use of a buffer system containing 2-(N-morpholino)ethanesulfonic acid/histidine (MES/His) as working electrolytes, and complexing agents, such as 18-crown-6 ether, acetic acid, citric acid, lactic acid, and 2-hydroxyisobutyric acid as additives [16] [17] [18] [19]. In this study, we developed a simple and compact $\mathrm{CE}-\mathrm{C}^{4} \mathrm{D}$ method based on citric acid buffer solution (Cit) by using 18-crown-6 ether and hexadecyltrimethylammonium bromide (CTAB) as complexing reagents to determine $\mathrm{K}^{+}, \mathrm{Na}^{+}, \mathrm{Sr}^{2+}, \mathrm{Mg}^{2+}$, and $\mathrm{Ca}^{2+}$ ions. The proposed method was successfully applied to the quantitation of above metal ions in six different brands of drinking water.

\section{Experimental}

\subsection{Reagents, Solutions, and Samples}

All chemicals used were of analytical-grade. Acetic acid, L-histidine (His), MES, 18crown-6 ether, potassium chloride $(\mathrm{KCl})$, sodium chloride $(\mathrm{NaCl})$, magnesium chloride $\left(\mathrm{MgCl}_{2}\right)$, strontium chloride $\left(\mathrm{SrCl}_{2}\right)$, and calcium chloride $\left(\mathrm{CaCl}_{2}\right)$ were purchased from Sinopharm Chemical Reagent Co., Ltd. Organic additives, 18-crown-6 ether and CTAB were obtained from Aldrich (Milwaukee, WI, USA).

$\mathrm{KCl}, \mathrm{NaCl}, \mathrm{MgCl}_{2}, \mathrm{SrCl}_{2}$, and $\mathrm{CaCl}_{2}$ were dissolved in deionized water (Milli-Q water purification system, Millipore, Milford, MA) to prepare the stock solution with concentration of $100 \mathrm{mg} \cdot \mathrm{L}^{-1}$. For the analyses of inorganic ions, a $10 \mathrm{mM}$ stock solution of 18-crown- 6 ether and $1 \mathrm{mM}$ stock solution of CTAB were prepared and added to the running buffer in order to allow the complete separation of five metal ions. Fresh running buffer solutions were prepared daily. All the solutions were stored in a refrigerator at $4^{\circ} \mathrm{C}$ until their use. Prior to the experiments, all the solutions were filtered through $0.22 \mu \mathrm{m}$ polypropylene Acrodisc syringe filter (Xinya Purification Instrument Factory, Shanghai, China) and sonicated for $5 \mathrm{~min}$ to remove bubbles.

Drinking water samples were obtained from local supermarket in Shanghai, China. Prior to the analysis, the water samples were filtered through polypropylene Acrodisc syringe filter (nominal pore size $0.22 \mu \mathrm{m}$ ). All the samples were kept in a refrigerator until the experiments were performed and were diluted to specified concentration in our testing range with the buffer solution prior to analyses. 


\subsection{Instrumentation and Analytical Procedure}

The CE-C $C^{4} \mathrm{D}$ system used was similar to a previously reported system [20]. A high- voltage power supply $(0 \pm 30 \mathrm{kV}$, Shanghai Institute of Nuclear Research, Shanghai, China) was utilized. Electrochemistry experiments were performed on a capacitively coupled contactless conductivity detector (eDAQ, Denistone East, NSW, Australia). The $\mathrm{C}^{4} \mathrm{D}$ operates with a sine-wave signal at a frequency of $600 \mathrm{KHz}$ and an effective voltage of $65 \mathrm{~V}$. Analyses were performed in uncoated fused silica capillaries (Yongnian Optical Fiber Factory, Hebei, China) with an internal diameter of $75 \mu \mathrm{m}$, an external diameter of $375 \mu \mathrm{m}$, and a total length of $65 \mathrm{~cm}$ (effective length of $50 \mathrm{~cm}$ ). Each new capillary was activated by sequentially flowing (pressure driven by a medicine syringe) $0.5 \mathrm{M}$ hydrochloric acid, $0.5 \mathrm{M}$ sodium hydroxide $(\mathrm{NaOH})$ solution, deionized water, and then the running buffer for $30 \mathrm{~min}$, respectively. The capillary was then equilibrated in the buffer under an electric field of $17 \mathrm{kV}$ for about $30 \mathrm{~min}$ prior to the sample injection. Otherwise, pretreatment was carried out daily by washing with $0.1 \mathrm{M}$ $\mathrm{NaOH}$ solution, deionized water and running buffer for $5 \mathrm{~min}$, respectively. The capillary was rinsed with the running buffer between analyses to improve reproducibility. A voltage of $30 \mathrm{kV}$ was then applied for $60 \mathrm{~min}$ with the BGE. Data acquisition and analysis were preformed using e-corder data acquisition system powerchrom 280 (eDAQ, Denistone East, NSW, Australia). The pH was monitored using a PHS-3C Acidometer (Shanghai Jicheng Instrument Factory, China). Experiments were performed at constant laboratory temperature of $24^{\circ} \mathrm{C} \pm 1^{\circ} \mathrm{C}$ measured inside the detection compartment of the $\mathrm{CE}-\mathrm{C}^{4} \mathrm{D}$ system.

All the quantitative determinations of metal ions in drinking water samples were made by the standard addition method $(n=3)$, where the peak area obtained for each analyte was used for quantitative interpretation and calculations. All data treatment was performed by using Microcal Origin 7.0 (Microcal Software, Northampton, MA, USA).

\section{Results and Discussion}

\subsection{Optimization of Separation Conditions}

\subsubsection{Selection of Running Buffer Solution}

In $C^{4} \mathrm{D}$, the response arises from the difference in conductivity between analytes and BGE co-ions. In order to achieve a high signal-to-noise ratio $(\mathrm{S} / \mathrm{N})$, a large difference between the conductance of the analytes and electrolyte is needed [21] [22]. The BGE employing MES/His has commonly been used as a running buffer for the separation of small ions in $\mathrm{CE}-\mathrm{C}^{4} \mathrm{D}$ attributed to its low specific conductivity and significantly high ionic strength. Unfortunately, for the separation of $\mathrm{K}^{+}, \mathrm{Na}^{+}, \mathrm{Mg}^{2+}, \mathrm{Sr}^{2+}$, and $\mathrm{Ca}^{2+}$ ions, this BGE is not ideal because the peaks corresponding to $\mathrm{Na}^{+}$and $\mathrm{Mg}^{2+}$ strongly overlap with the peaks corresponding to $\mathrm{Ca}^{2+}$ and $\mathrm{Sr}^{2+}$, respectively (Figure 1). Therefore, similarities in the effective ionic radii and equivalent conductance imposed the need for the addition of an auxiliary complexing agent of considerably low $\mathrm{pH}(3-5)$ to the BGE, in order to achieve the complete separation of the cationic species [23]. Therefore, for varying the complexing constant of the complexing agent, an ideal approach involved the 


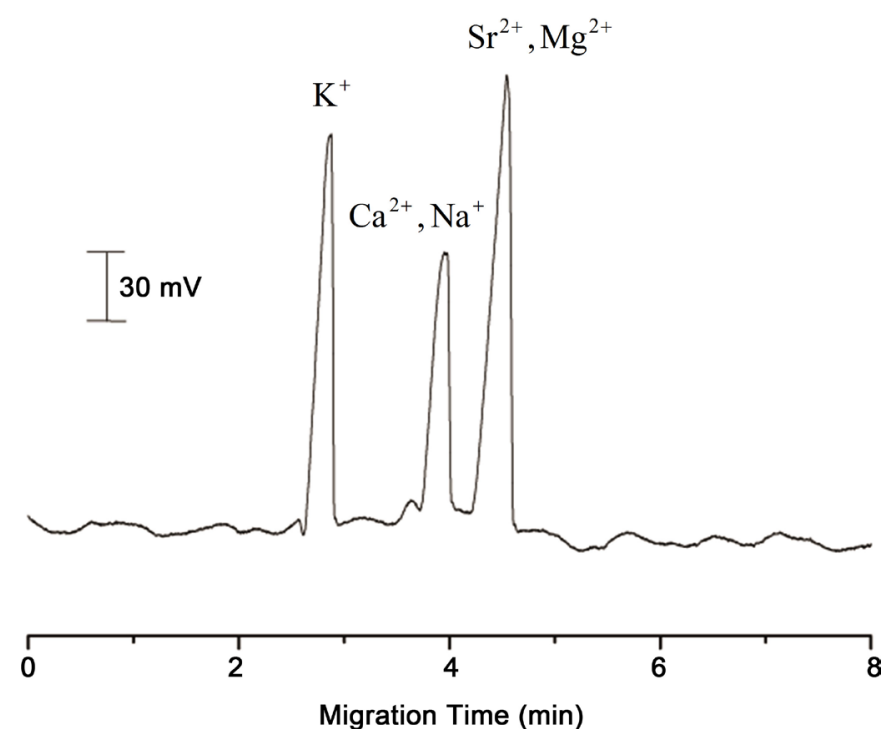

Figure 1. Electropherograms for mixture containing $\mathrm{K}^{+}, \mathrm{Ca}^{2+}, \mathrm{Na}^{+}, \mathrm{Sr}^{2+}$, and $\mathrm{Mg}^{2+}$ ions. The concentration of five metal ions was $5 \mathrm{mg} \cdot \mathrm{L}^{-1}$. Electrolyte: $10 \mathrm{mM}$ MES $+10 \mathrm{mM}$ His; Capillary column: $50 \mathrm{~cm} \times 75 \mu \mathrm{m}$; separation voltage: $+16 \mathrm{kV}$; injection: electrokinetic injection using a voltage of $16 \mathrm{kV}$ for $4 \mathrm{~s}$. Sample diluted with running buffer.

replacement of MES/His by Cit, capable of complexing with $\mathrm{Mg}^{2+}$ and $\mathrm{Sr}^{2+}$, and $\mathrm{Ca}^{2+}$ at low $\mathrm{pH}$. In systems involving contactless conductivity detection, parameters such as concentration of the electrolyte solution, $\mathrm{pH}$ of the $\mathrm{BGE}$, and concentration of the complexing agents must be taken into account; therefore, in this study, these parameters were investigated in detail.

\subsubsection{Effect of Concentration of Cit}

Next parameter investigated was the concentration of Cit in the BGE. The effect of the concentration of Cit on the migration time was studied in the range $8-15 \mathrm{mM}$. Figure 2 exhibits the effect of the concentration of Cit on the migration time, revealing that an increase in the concentration of Cit improves the separation degree of $\mathrm{K}^{+}, \mathrm{Na}^{+}, \mathrm{Mg}^{2+}$, $\mathrm{Sr}^{2+}$, and $\mathrm{Ca}^{2+}$ ions; however, higher concentration of Cit beyond $15 \mathrm{mM}$ leads to comigration of $\mathrm{Na}^{+}, \mathrm{Ca}^{2+}$ and $\mathrm{Mg}^{2+}, \mathrm{Sr}^{2+}$. Moreover, $15 \mathrm{mM}$ Cit is disadvantageous to the resolution and separation efficiency, making the baseline unstable and fluctuant at a separation voltage of $16 \mathrm{kV}$ due to the excess Joule heat. Consequently, for a simultaneous separation of metal ions, it was better to select an optimized electrolyte concentration of $12 \mathrm{mM}$ Cit.

\subsubsection{Effect of CTAB Concentration}

In order to improve the resolution of analytes, a small amount of the cationic surfactant $\mathrm{CTAB}$ was added to the BGE. Adsorption of $\mathrm{CTAB}$ micelles onto the capillary surface resulted in the formation of a layer with positive charge causing a reduction or even a complete reversal of the electroosmotic flow. Figure 3 shows the effect of the CTAB concentration in the electrolyte on the migration times for the selected ions. Notably, with an increase in the concentration of $\mathrm{CTAB}$, the separation of ions migration be- 


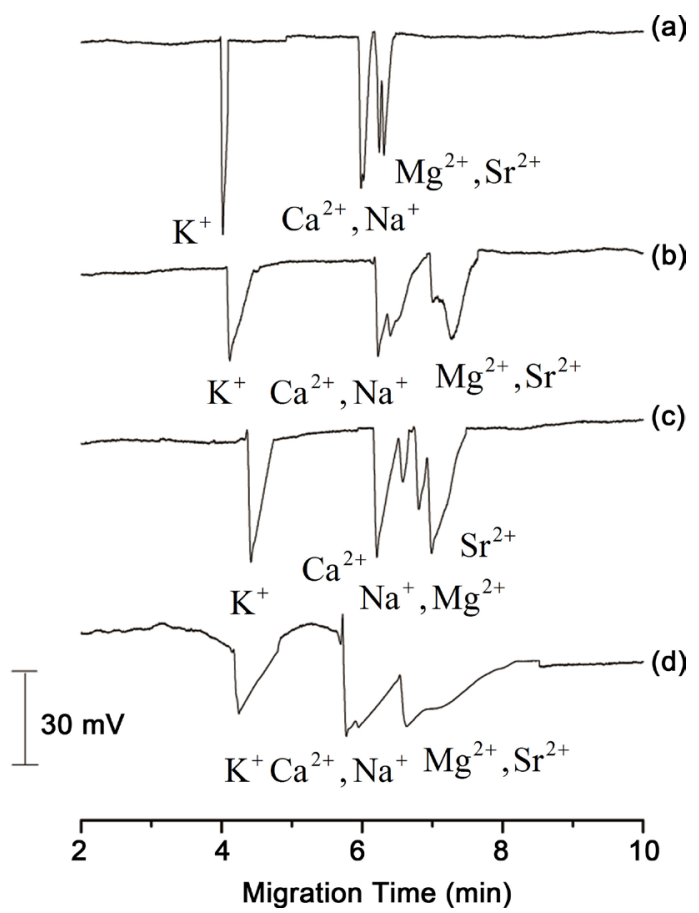

Figure 2. Influence of the Cit concentration on the separation of five metal ions. (a) $8 \mathrm{mM}$ Cit; (b) $10 \mathrm{mM}$ Cit; (c) $12 \mathrm{mM}$ Cit; and (d) $15 \mathrm{mM}$ Cit; concentration of $\mathrm{K}^{+}, \mathrm{Ca}^{2+}, \mathrm{Na}^{+}, \mathrm{Mg}^{2+}$, and $\mathrm{Sr}^{2+}$ were $3,5,5,5$, and $12 \mathrm{mg} \cdot \mathrm{L}^{-1}$, respectively. Other conditions were similar to those mentioned in Figure 1.

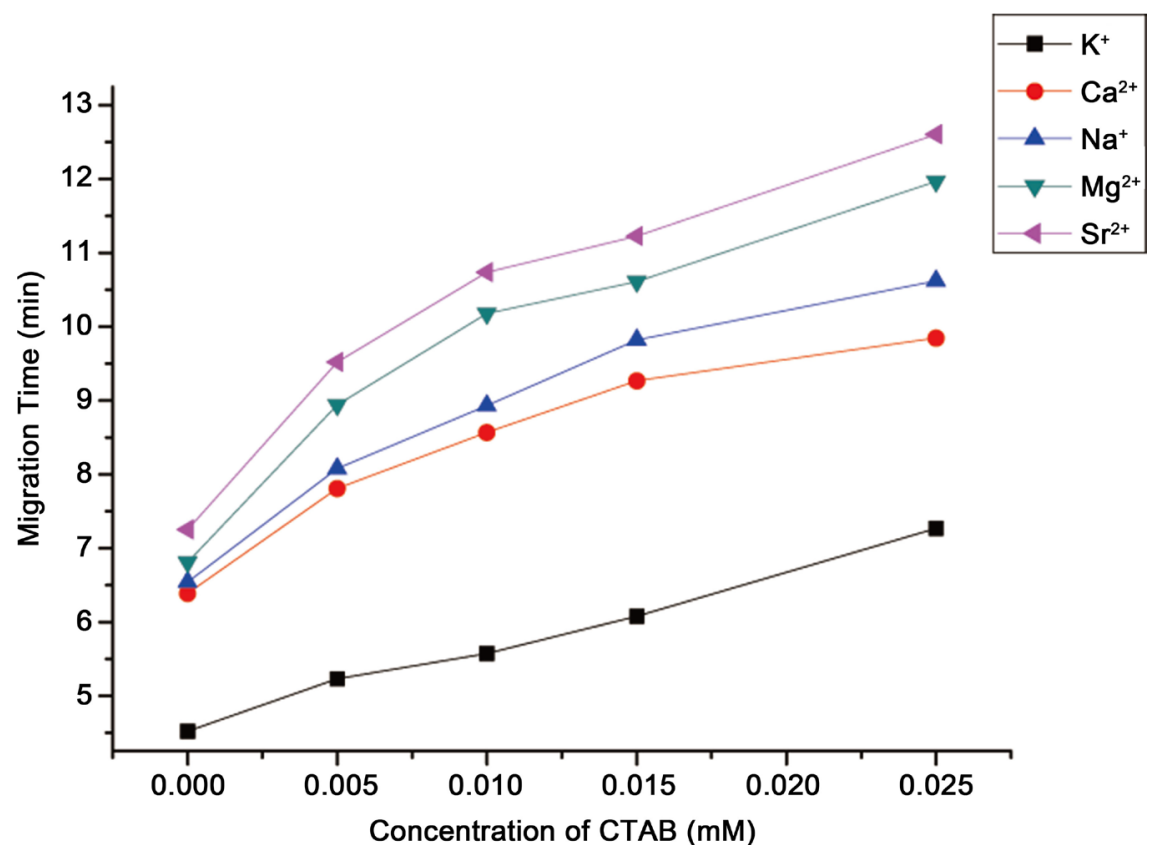

Figure 3. Influence of the CTAB concentration on the separation of five metal ions. Other conditions were similar to those mentioned in Figure 2.

tween $\mathrm{Ca}^{2+}$ and $\mathrm{Na}^{+}$improves. Nonetheless, the baseline becomes unstable and resolution of the five metal ions becomes worse due to higher concentration of CTAB (0.02 
$\mathrm{mM}$ ). Thus, CTAB concentration of $0.015 \mathrm{mM}$ seemed to be a suitable compromise and was selected as the optimized concentration.

\subsubsection{Effect of 18-Crown-6 Ether on Electromigration}

Under the tested experimental conditions discussed above, a phenomenon was observed that $\mathrm{Sr}^{2+}$ and $\mathrm{Mg}^{2+}$ could not be separated completely by using only Cit buffer and CTAB. The separation of some comigrating cations can be fine-tuned by the addition of 18-crown-6 ether to the BGE. 18-Crown-6 ether is known to form inclusion complexes with several inorganic cations, such as $\mathrm{K}^{+}$and $\mathrm{Sr}^{2+}$. The complex formation depends on the sizes of both the cation and the crown ether cavity. Figure 4 illustrates the influence of the addition of 18-crown- 6 ether to the electrolyte with a constant concentration of $\mathrm{Cit}$ at $\mathrm{pH} 3.5$. The crown ether concentration was varied in the range 0 - $0.3 \mathrm{mM}$. The migration times of some ions did not change significantly. However, the migration time of $\mathrm{K}^{+}$and $\mathrm{Sr}^{2+}$ ions was significantly influenced. Consequently, Figure 4 exhibits that the electrolyte containing $0.2 \mathrm{mM} 18$-crown-6 ether concentration provides a complete baseline separation of $\mathrm{Sr}^{2+}$ and $\mathrm{Mg}^{2+}$ ions.

\subsubsection{Effect of Injection Time}

Furthermore, effect of the injection time ranging from 2 to $10 \mathrm{~s}$ was investigated. Variation of the injection time from 2 - $10 \mathrm{~s}$ at $17 \mathrm{kV}$ led to an increase in the peak heights of these five cations. However, simultaneously the band broadening of signals and low separation efficiency were also observed. When the injection time exceeded $6 \mathrm{~s}$, the problem related to peak broadening in conjunction with peak distortion became more obvious (results not shown). Thus, the abovementioned discussion indicated that $6 \mathrm{~s}$ in-

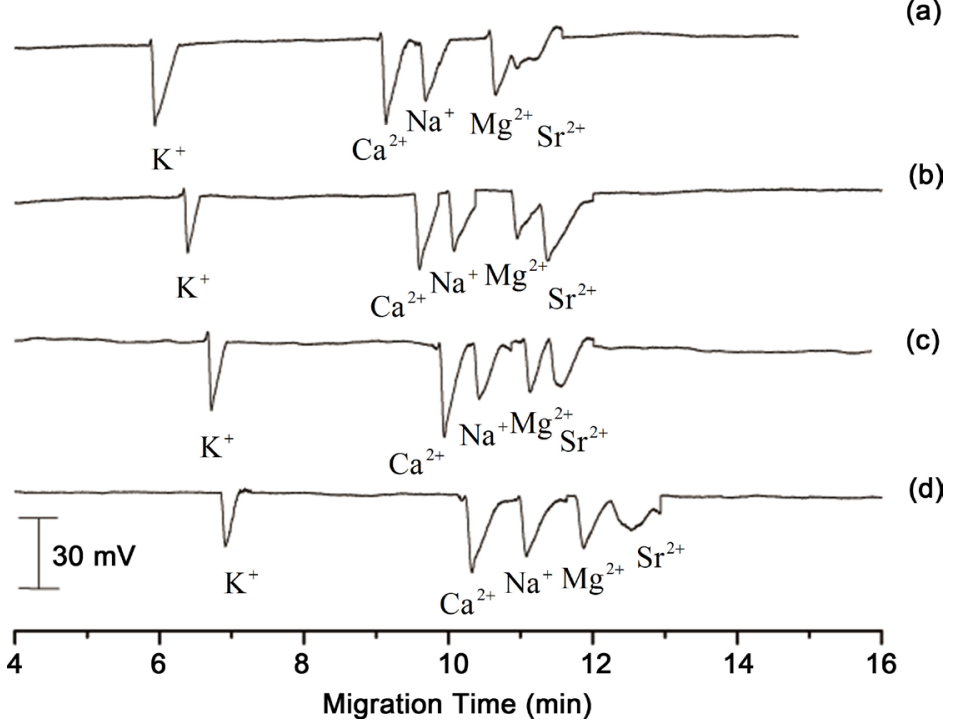

Figure 4. Influence of 18-crown-6 ether concentration on separation of metal ions. (a) $12 \mathrm{mM}$ Cit + 0.015 mM CTAB; (b) $12 \mathrm{mM} \mathrm{Cit} \mathrm{+} 0.015 \mathrm{mM} \mathrm{CTAB}+0.1 \mathrm{mM} 18$-crown-6 ether; (c) 12 $\mathrm{mM}$ Cit $+0.015 \mathrm{mM} \mathrm{CTAB}+0.2 \mathrm{mM} 18$-crown-6 ether; and (d) $12 \mathrm{mM} \mathrm{Cit}+0.015 \mathrm{mM} \mathrm{CTAB}$ $+0.3 \mathrm{mM} 18$-crown-6 ether; $\mathrm{pH} 3.5$; other conditions were similar to those mentioned in Figure 3. 


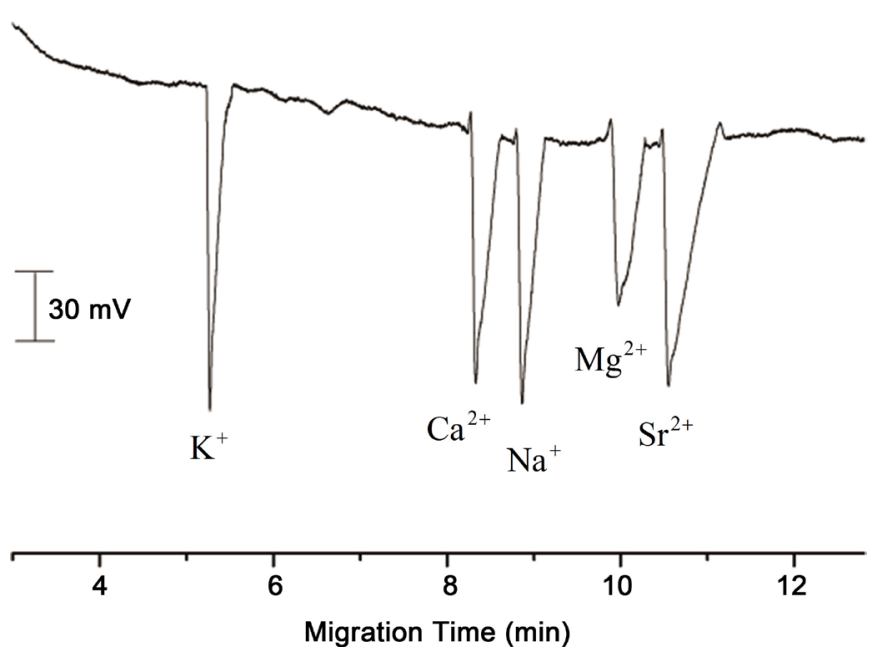

Figure 5. Electropherogram for separation of five metal ions. Conditions: capillary column: 65 $\mathrm{cm} \times 75 \mu \mathrm{m}$; separation voltage: $17 \mathrm{kV}$; Electrolyte: $12 \mathrm{mM}$ Cit $+0.015 \mathrm{mM} \mathrm{CTAB}+0.2 \mathrm{mM}$ 18-crown-6 ether; $\mathrm{pH}$ : 3.5; The concentration of $\mathrm{K}^{+}, \mathrm{Ca}^{2+}, \mathrm{Na}^{+}, \mathrm{Mg}^{2+}, \mathrm{Sr}^{2+}$ ions were 4, 8, 6, 4, and $18 \mathrm{mg} \cdot \mathrm{L}^{-1}$, respectively. Samples were dissolved in running buffer; electrokinetic injection using a voltage of $17 \mathrm{kV}$ for $6 \mathrm{~s}$.

jection time could be selected as the optimal condition.

Above parameters related to BGEs showed that simultaneous determination of five metal ions in the real samples was possible. The electrolyte solution consisted of $12 \mathrm{mM}$ Cit, 0.015 mM CTAB, and $0.2 \mathrm{mM} 18$-crown- 6 ether at pH 3.5 (monitored by a PHS-3C Acidometer). The optimal injection time and separation voltage were $6 \mathrm{~s}$ and $17 \mathrm{kV}$, respectively. The separation was achieved in less than $12 \mathrm{~min}$. The total capillary length used was $75 \mathrm{~cm}$ and the effective capillary length was $65 \mathrm{~cm}$. The resulting electropherograms of the simultaneous determination of five metal ions are depicted in Figure 5.

\subsection{Evaluation of the Developed Method}

In order to evaluate the developed method for the quantitative purpose, linearity figures and limits of detection (LOD) were determined. The linearity of the method was determined by constructing a calibration curve with different concentrations of the five metal ions. The linear regression coefficients were always higher than 0.9950. Repeatability of the relative area and migration time, expressed as relative standard deviations (RSD), was better than $5.1 \%$ and $2.3 \%(\mathrm{n}=8)$, respectively, indicating a high degree of precision. All the validation data are listed in Table 1.

The detection limits (the concentrations providing peak heights which are 3 times as tall as the baseline noise) for $\mathrm{K}^{+}, \mathrm{Na}^{+}, \mathrm{Mg}^{2+}, \mathrm{Sr}^{2+}, \mathrm{Ca}^{2+}$ ions were determined to be below $0.2 \mathrm{mg} \cdot \mathrm{L}^{-1}$ for all but one of the ions for this experimental system, which is well below the requirements for the application envisaged.

\subsection{Sample Analyses}

The methodology based on the CE- $\mathrm{C}^{4} \mathrm{D}$ was applied to the analysis of five metal ions in six different drinking matrices. The quantitative results (obtained using a calibration 
Table 1. The results of linearity, LOD, and precision.

\begin{tabular}{ccccccc}
\hline Compound & $\begin{array}{c}\text { Linear } \\
\text { regression }\end{array}$ & $\begin{array}{c}\text { Linearity } \\
\left(\mathrm{mg} \cdot \mathrm{L}^{-1}\right)\end{array}$ & $\begin{array}{c}\text { Correlation } \\
\left(\mathrm{R}^{2}\right)\end{array}$ & $\begin{array}{c}\text { LOD } \\
\left(\mathrm{mg} \cdot \mathrm{L}^{-1}\right)\end{array}$ & $\begin{array}{c}\mathrm{RSD} \% \\
(\mathrm{time})\end{array}$ & $\begin{array}{c}\mathrm{RSD} \% \\
(\mathrm{area})\end{array}$ \\
\hline $\mathrm{K}^{+}$ & $\mathrm{y}=10.387 \mathrm{x}+1.146$ & $0.05-20$ & 0.9973 & 0.02 & 1.3 & 2.7 \\
$\mathrm{Ca}^{2+}$ & $\mathrm{y}=3.747 \mathrm{x}+0.151$ & $0.25-20$ & 0.9968 & 0.1 & 2.1 & 3.6 \\
$\mathrm{Na}^{+}$ & $\mathrm{y}=4.837 \mathrm{x}+0.766$ & $0.1-15$ & 0.9984 & 0.05 & 1.7 & 4.8 \\
$\mathrm{Sr}^{2+}$ & $\mathrm{y}=1.671 \mathrm{x}+0.058$ & $0.4-15$ & 0.9955 & 0.2 & 2.3 & 5.1 \\
$\mathrm{Mg}^{2+}$ & $\mathrm{y}=5.076 \mathrm{x}+0.612$ & $0.1-20$ & 0.9972 & 0.05 & 1.4 & 4.2 \\
\hline
\end{tabular}

${ }^{\mathrm{a}}$ Linear regression based on peak area $\left(\mathrm{mV}\right.$ s) vs. concentration $\left(\mathrm{mg} \cdot \mathrm{L}^{-1}\right)$.

${ }^{\mathrm{b}}$ Estimated on the basis of $\mathrm{S} / \mathrm{N}=3$.

Table 2. Quantitative analysis of real samples ${ }^{\mathrm{a}}$. ND: not detected.

\begin{tabular}{cccccc}
\hline \multirow{2}{*}{ Sample } & \multicolumn{5}{c}{ Cation concentration $\left(\mathrm{mg} \cdot \mathrm{L}^{-1}\right)^{\mathrm{b}}$} \\
\cline { 2 - 5 } & $\mathrm{K}^{+}$ & $\mathrm{Ca}^{2+}$ & $\mathrm{Na}^{+}$ & $\mathrm{Sr}^{2+}$ & $\mathrm{Mg}^{2+}$ \\
\hline 1 & 8.2 & 34.8 & 5.7 & 0.5 & 36.3 \\
2 & $\mathrm{ND}$ & 69.2 & 3.8 & 0.8 & 10.9 \\
3 & 3.1 & 2.7 & 4.5 & 0.6 & $\mathrm{ND}$ \\
4 & 2.9 & 54.2 & 43.9 & 0.6 & 9.4 \\
5 & 4.3 & 21.9 & 15.5 & $\mathrm{ND}$ & 8.2 \\
6 & 0.61 & 51.7 & 2.1 & $\mathrm{ND}$ & 5.4 \\
\hline
\end{tabular}

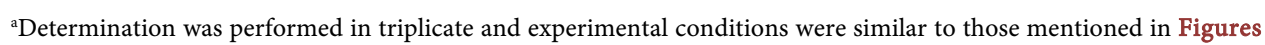
3-5.

${ }^{\mathrm{b}} \mathrm{RSD}(\mathrm{n}=3): 3 \%-10 \%$.

curve method) are listed in Table 2. The values listed in Table 2 indicate the presence and quantification of the metal ions $\mathrm{Ca}^{2+}$ and $\mathrm{Na}^{+}$ions in all the samples, and existence of $\mathrm{K}^{+}, \mathrm{Sr}^{2+}$, and $\mathrm{Mg}^{2+}$ ions in some samples.

\section{Conclusion}

The perfect separation of metal ions $\mathrm{K}^{+}, \mathrm{Na}^{+}, \mathrm{Mg}^{2+}, \mathrm{Sr}^{2+}$, and $\mathrm{Ca}^{2+}$ in drinking water samples could be achieved by CE- $\mathrm{C}^{4} \mathrm{D}$ using a Cit buffer solution containing $\mathrm{CTAB}$ and 18-crown-6 ether as complexing reagents. The proposed method did not require any sample retreatment, except dilution with running buffer, and thus did not significantly change the composition of the original sample. It was easy to optimize the composition of the running buffer by using a conductivity detector. Under the optimal conditions, the developed method exhibited a very good quantitative performance in terms of accuracy and precision with an analysis time of less than 12 min for all the ions.

\section{Acknowledgements}

This work was financially supported by the national program on development of scientific instruments and equipments (2011YQ150072), the National Natural Science Foundation of China (No. 21575042) and the talent development program of Minhang District. 


\section{References}

[1] da Silva, J.A.F., Ricelli, N.L., Carvalhoand, A.Z. and do Lago, C.L. (2003) Improved Separation of IA and IIA Metal Cations in Matrices with High Sodium Concentration by Capillary Electrophoresis with Contactless Conductometric Detection. Journal of the Brazilian Chemical Society, 14, 265-268. http://dx.doi.org/10.1590/S0103-50532003000200013

[2] Wan, Q.J., Kuban, P., Tanyanyiwa, J., Rainelli, A. and Hauser, P.C. (2004) Determination of Major Inorganic Ions in Blood Serum and Urine by Capillary Electrophoresis with Contactless Conductivity Detection. Analytica Chimica Acta, 525, 11-16.

http://dx.doi.org/10.1016/j.aca.2004.08.002

[3] Saad, B., Wei Pok, F., Sujari, A.N.A. and Idiris Saleh, M. (1998) Analysis of Anions and Cations in Drinking Water Samples by Capillary Ion Analysis. Food Chemistry, 61, 249-254. http://dx.doi.org/10.1016/S0308-8146(97)00024-1

[4] Zhang, S., Wang, L., Dang, Z., Li, T., Liu, X., et al. (2007) Compact Design for a Square Wave Excitation Contactless Conductivity Detector: Determination of Metal Cations in Environmental Water Samples. Instrumentation Science \& Technology, 35, 275-294. http://dx.doi.org/10.1080/10739140701255599

[5] Liu, B., Zhang, Y., Mayer, D., Krause, H.J., Jin, Q., et al. (2012) Determination of Heavy Metal Ions by Microchip Capillary Electrophoresis Coupled with Contactless Conductivity Detection. Electrophoresis, 33, 1247-1250. http://dx.doi.org/10.1002/elps.201100626

[6] Jandik, P. and Jones, W.R. (1991) Optimization of Detection Sensitivity in the Capillary Electrophoresis of Inorganic Anions. Journal of Chromatography A, 546, 431-443. http://dx.doi.org/10.1016/S0021-9673(01)93042-0

[7] Beck, W. and Engelhardt, H. (1993) Separation of Non UV-Absorbing Cations by Capillary Electrophoresis. Fresenius' Journal of Analytical Chemistry, 346, 618-621. http://dx.doi.org/10.1007/BF00321257

[8] Baltussen, E., Guijt, R.M., Steen, G.V.D., Laugere, F., Baltussen, S., et al. (2002) Considerations on contactless Conductivity Detection in Capillary Electrophoresis. Electrophoresis, 23, 2888-2893. http://dx.doi.org/10.1002/1522-2683(200209)23:17<2888::AID-ELPS2888>3.0.CO;2-4

[9] Pantsar-Kallio, M. and Manninen, P.K. (1995) Determination of Sodium, Potassium, Calcium and Magnesium Cations by Capillary Electrophoresis Compared with Ion Chromatography. Analytica Chimica Acta, 314, 67-75. http://dx.doi.org/10.1016/0003-2670(95)00266-3

[10] Yang, Q., Jimidar, M., Hamoir, T., Smeyers-Verbeke, J. and Massart, D. (1994) Determination of Alkali and Alkaline Earth Metals in Real Samples by Capillary Ion Analysis. Journal of Chromatography A, 673, 275-285. http://dx.doi.org/10.1016/0021-9673(94)85044-5

[11] Bergamo, A.B., Da Silva, J.A.F. and De Jesus, D.P. (2011) Simultaneous Determination of Aspartame, Cyclamate, Saccharin and Acesulfame-K in Soft Drinks and Tabletop Sweetener Formulations by Capillary Electrophoresis with Capacitively Coupled Contactless Conductivity Detection. Food Chemistry, 124, 1714-1717. http://dx.doi.org/10.1016/j.foodchem.2010.07.107

[12] Wan, Q.J., Kubáň, P., Tanyanyiwa, J., Rainelli, A. and Hauser, P.C. (2004) Determination of Major Inorganic Ions in Blood Serum and Urine by Capillary Electrophoresis with Contactless Conductivity Detection. Analytica Chimica Acta, 525, 11-16.

http://dx.doi.org/10.1016/j.aca.2004.08.002

[13] Fritz, J.S. (2000) Recent Developments in the Separation of Inorganic and Small Organic Ions by Capillary Electrophoresis. Journal of Chromatography A, 884, 261-275. 
http://dx.doi.org/10.1016/S0021-9673(00)00186-2

[14] Kubáň, P., Karlberg, B., Kubáň, P. and Kubáň, V. (2002) Application of a Contactless Conductometric Detector for the Simultaneous Determination of Small Anions and Cations by Capillary Electrophoresis with Dual-Opposite End Injection. Journal of Chromatography $A$, 964, 227-241. http://dx.doi.org/10.1016/S0021-9673(02)00656-8

[15] Timerbaev, A.R. (2004) Capillary Electrophoresis of Inorganic Ions: An Update. Electrophoresis, 25, 4008-4031. http://dx.doi.org/10.1002/elps.200406111

[16] de Carvalho, L.M., Spengler, C., de Lima, A.P.S., Raabe, A., Martini, M., et al. (2009) Determinação simultânea de cátions empregando eletroforese capilar com detecção condutométrica sem contato em equipamento construído em laboratório. Química Nova, 32, 2203-2208. http://dx.doi.org/10.1590/S0100-40422009000800036

[17] Kubáň, P., Kubáň, P. and Kubáň, V. (2002) Simultaneous Determination of Inorganic and Organic Anions, Alkali, Alkaline Earth and Transition Metal Cations by Capillary Electrophoresis with Contactless Conductometric Detection. Electrophoresis, 23, 3725-3734. http://dx.doi.org/10.1002/1522-2683(200211)23:21<3725::AID-ELPS3725>3.0.CO;2-9

[18] Kubáň, P. and Hauser, P.C. (2009) Ten Years of axial Capacitively Coupled Contactless Conductivity Detection for CZE-A Review. Electrophoresis, 30, 176-188. http://dx.doi.org/10.1002/elps.200800478

[19] Zemann, A., Rohregger, I. and Zitturi, R. (2008) Determination of Small Ions with Capillary Electrophoresis and Contactless Conductivity Detection. Capillary Electrophoresis. Springer, Berlin, 3-19. http://dx.doi.org/10.1007/978-1-59745-376-9 1

[20] Gao, F., Wu, M., Zhang, Y., Wang, G., Wang, Q., et al. (2014) Sensitive Determination of Four Beta(2)-Agonists in Pig Feed by Capillary Electrophoresis Using On-Line Sample Preconcentration with Contactless Conductivity Detection. Journal of Chromatography B-Analytical Technologies in the Biomedical and Life Sciences, 973, 29-32. http://dx.doi.org/10.1016/j.jchromb.2014.10.004

[21] Vrouwe, E.X., Luttge, R., Olthuis, W. and van den Berg, A. (2006) Rapid Inorganic Ion Analysis Using Quantitative Microchip Capillary Electrophoresis. Journal of Chromatography $A, 1102$, 287-293. http://dx.doi.org/10.1016/j.chroma.2005.10.064

[22] Nussbaumer, S., Fleury-Souverain, S., Bouchoud, L., Rudaz, S., Bonnabry, P., et al. (2010) Determination of Potassium, Sodium, Calcium and Magnesium in Total Parenteral Nutrition Formulations by Capillary Electrophoresis with Contactless Conductivity Detection. Journal of Pharmaceutical and Biomedical Analysis, 53, 130-136. http://dx.doi.org/10.1016/j.jpba.2010.01.042

[23] De Carvalho, L.M., Raabe, A., Martini, M., Sant'anna, C.S., Da Silveira, G.D., et al. (2011) Contactless Conductivity Detection of 14 Inorganic Cations in Mineral and Phytotherapeutic Formulations after Capillary Electrophoretic Separation. Electroanalysis, 23, 2574-2581. http://dx.doi.org/10.1002/elan.201100272 
Submit or recommend next manuscript to SCIRP and we will provide best service for you:

Accepting pre-submission inquiries through Email, Facebook, LinkedIn, Twitter, etc.

A wide selection of journals (inclusive of 9 subjects, more than 200 journals)

Providing 24-hour high-quality service

User-friendly online submission system

Fair and swift peer-review system

Efficient typesetting and proofreading procedure

Display of the result of downloads and visits, as well as the number of cited articles

Maximum dissemination of your research work

Submit your manuscript at: http://papersubmission.scirp.org/

Or contactajac@scirp.org 